NATIONAL LABORATORY

\title{
Preliminary Examination of Ethanol Fuel Effects on EPA's R-factor for Vehicle Fuel Economy
}

\section{June 2013}

Prepared by C. Scott Sluder Brian H. West

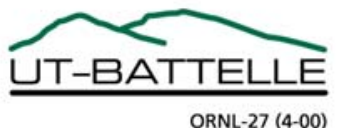




\section{DOCUMENT AVAILABILITY}

Reports produced after January 1, 1996, are generally available free via the U.S. Department of Energy (DOE) Information Bridge.

Web site http://www.osti.gov/bridge

Reports produced before January 1, 1996, may be purchased by members of the public from the following source.

National Technical Information Service

5285 Port Royal Road

Springfield, VA 22161

Telephone 703-605-6000 (1-800-553-6847)

TDD 703-487-4639

Fax 703-605-6900

E-mail info@ntis.gov

Web site http://www.ntis.gov/support/ordernowabout.htm

Reports are available to DOE employees, DOE contractors, Energy Technology Data Exchange (ETDE) representatives, and International Nuclear Information System (INIS) representatives from the following source.

Office of Scientific and Technical Information

P.O. Box 62

Oak Ridge, TN 37831

Telephone 865-576-8401

Fax 865-576-5728

E-mail reports@osti.gov

Web site http://www.osti.gov/contact.html

This report was prepared as an account of work sponsored by an agency of the United States Government. Neither the United States Government nor any agency thereof, nor any of their employees, makes any warranty, express or implied, or assumes any legal liability or responsibility for the accuracy, completeness, or usefulness of any information, apparatus, product, or process disclosed, or represents that its use would not infringe privately owned rights. Reference herein to any specific commercial product, process, or service by trade name, trademark, manufacturer, or otherwise, does not necessarily constitute or imply its endorsement, recommendation, or favoring by the United States Government or any agency thereof. The views and opinions of authors expressed herein do not necessarily state or reflect those of the United States Government or any agency thereof. 
ORNL/TM-2012/198

\title{
PRELIMINARY EXAMINATION OF ETHANOL FUEL EFFECTS ON EPA'S R-FACTOR FOR VEHICLE FUEL ECONOMY
}

\author{
C. Scott Sluder \\ Brian H. West \\ Oak Ridge National Laboratory
}

Date Published: June 2013

Prepared by

OAK RIDGE NATIONAL LABORATORY

Oak Ridge, Tennessee 37831-6283

managed by

UT-BATTELLE, LLC

for the

U.S. DEPARTMENT OF ENERGY

under contract DE-AC05-00OR22725 



\section{CONTENTS}

Page

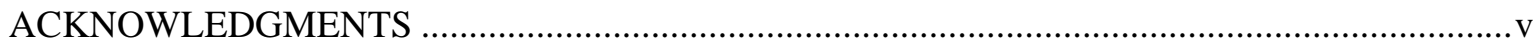

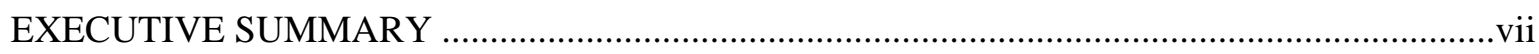

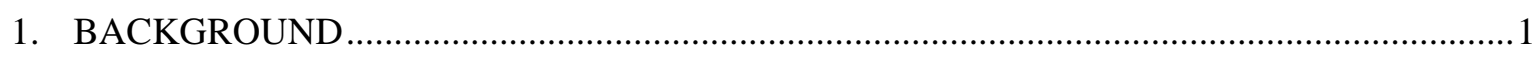

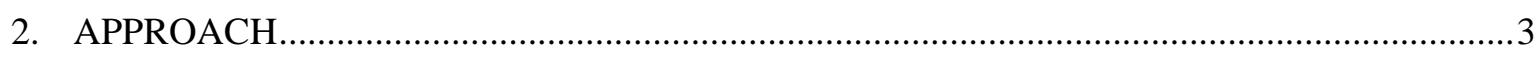

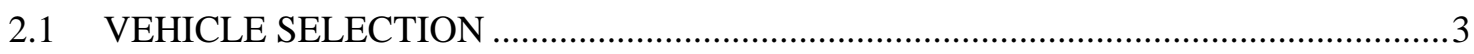

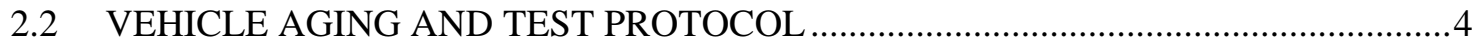

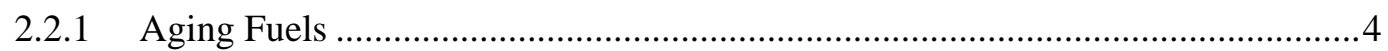

2.2.2 Emissions Test Fuels ....................................................................................

2.2.3 Adjustment of Carbon Weight Fraction for Some Fuels ........................................5

2.2.4 Adjustment of Fuel Heating Values for Some Fuels ............................................6

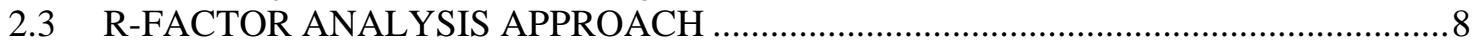

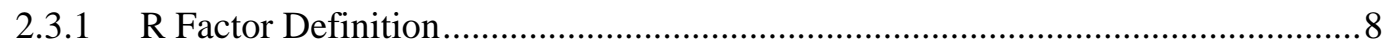

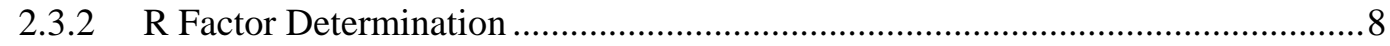

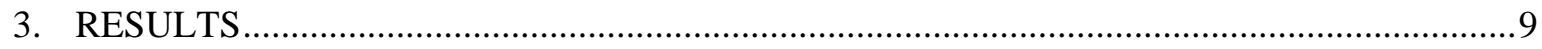

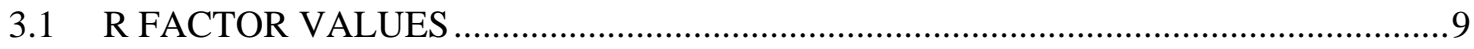

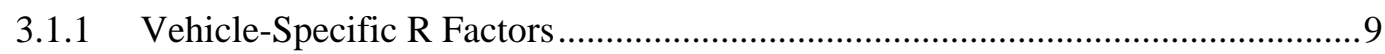

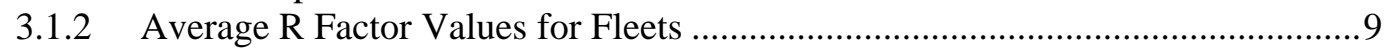

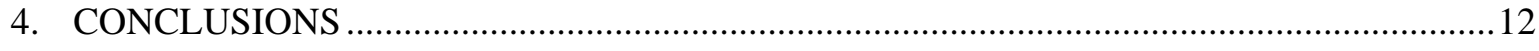

APPENDIX A. BIBLIOGRAPHY OF INTERMEDIATE ETHANOL BLENDS STUDIES ..........13 



\section{ACKNOWLEDGMENTS}

This report and the work described were sponsored by the U.S. Department of Energy (DOE) Office of Energy Efficiency and Renewable Energy (EERE) Vehicle Technologies Office. The authors gratefully acknowledge the support and direction of Kevin Stork and Steve Przesmitzki at DOE. This work has also benefited from input and direction from members of the Alliance of Automobile Manufacturers and the Coordinating Research Council. The authors are also indebted to the personnel of the Southwest Research Institute, and Transportation Research Center, in particular Marty Heimrich, Brent Shoffner, Karrie Honchell, and Walt Dudek, for their efforts in data collection during the DOE Intermediate Ethanol Blends Program.

The authors are grateful to many technical experts in industry and government. While these professionals provided valuable guidance and information as noted above, this consultation does not constitute endorsement by their organizations of either the study or the results. 



\section{EXECUTIVE SUMMARY}

The U.S. Department of Energy (DOE) supported a test program from 2007 through 2012 to evaluate the potential impacts of intermediate ethanol blends (also known as mid-level blends) on legacy vehicles and other engines. The purpose of the program was to assess the viability of using intermediate ethanol blends as a contributor to meeting national goals for the use of renewable fuels. Appendix A lists a bibliography of related studies. The catalyst durability program involved aging and emissions testing vehicles on a range of ethanol blends. The study was completed in 2011 and a final report issued shortly after.

This report describes a preliminary analysis of the fuel economy data from the catalyst durability study, to determine the proper value for the $\mathrm{R}$ factor which is called out in the Code of Federal Regulations (CFR) for computing vehicle fuel economy on the certification cycle. The fuel economy equation that is specified in CFR for gasoline-fuelled vehicles is based on a carbon mass balance (CMB) approach to determine the amount of fuel consumed during the test by measuring the carbon-bearing emissions that are produced; however, it also incorporates a scaling factor ( $\mathrm{R}$ factor) based on the net heating value of the fuel and the sensitivity of fuel economy to changes in the heating value. ${ }^{\dagger, \ddagger}$ The impact of the R factor is a fixed ratio in the resultant fuel economy that is dependent upon fuel properties other than those required for a typical CMB calculation. This equation was put in place in 1988 to correct for differences between certification fuels to address corporate average fuel economy (CAFE) credit issues associated with fuel property variations. The algorithm adjusts the calculated fuel economy to compute what would have been measured had the 1975 certification fuel been used for the test. The R factor was defined as the sensitivity of the fuel economy result to changes in fuel energy content. When R equals 1.0, the fuel economy change exactly tracks the energy density difference between the fuels. If $\mathrm{R}$ is less than 1.0 , the fuel economy change is smaller than the change in energy density. The $\mathrm{R}$ factor was defined to be 0.6 based on tests using 1980s vehicles. Since that time, the Auto/Oil test program has established that the R factor for 1990s vehicles is higher (about 0.93). ${ }^{\S}$ More recently EPA analyzed the EPAct/V2/E-89 dataset $^{* * *}$ to compute the $\mathrm{R}$ factor, resulting in an average of 0.82 to $0.86 .^{\dagger \dagger}$ It is important to note that the EPAct/V2/E89 test program used the LA92 test cycle, a cycle known to contain more aggressive accelerations than the FTP. ${ }^{\ddagger}$

To date, EPA has only required emissions and fuel economy testing of gasoline vehicles with a certification fuel that does not contain ethanol. However in 2013 EPA issued a Proposed Rule seeking comment on the establishment of an emissions certification fuel containing ethanol, such as E10 or E15. ${ }^{\S}$ Calculating modern vehicle fuel economy with the existing CFR equation with an $\mathrm{R}$ factor of 0.6 when ethanol blends are used produces significant errors. For the catalyst durability program, a straightforward

\footnotetext{
* West, Brian H., Scott Sluder, Keith Knoll, John Orban, Jingyu Feng, Intermediate Ethanol Blends Catalyst Durability Program, ORNL/TM-2011/234, February 2012, available at http://info.ornl.gov/sites/publications/Files/Pub31271.pdf

${ }^{\dagger}$ Federal Register Vol. 51(206), Friday, October 24, 1986, pp. 37844-37852.

${ }^{\ddagger} 40$ CFR Pt. 600.

${ }^{\S}$ Albert Hochhauser et al., "Fuel Composition Effects on Automotive Fuel Economy-Auto/Oil Air Quality Improvement Research Program,” SAE paper 930138, SAE International, Warrendale, Pennsylvania, March 1993.

** "EPAct/V2/E-89: Assessing the Effect of Five Gasoline Properties on Exhaust Emissions from Light-Duty Vehicles Certified to Tier 2 Standards, Final Report on Program Design and Data Collection”, Report Number EPA-420-R-13-004, March 2013

${ }^{{ }^{+}}$Aron Butler, David Good, Arvin Mitcham, “Analysis of the Effects of Changing Fuel Properties on the EPA Fuel Economy Equation and R-Factor,” Memorandum to Tier 3 Docket \#EPA-HQ-OAR-2011-0135, available at http://www.regulations.gov/\#!documentDetail;D=EPA-HQ-OAR-2011-0135-0604

\# Keith Knoll, Brian West, Wendy Clark, Ronald Graves, John Orban, Steve Przesmitzki, Timothy Theiss, Effects of Intermediate Ethanol Blends on Legacy Vehicles and Small Non-Road Engines, Report 1-Updated, NREL/TP-540-43543, ORNL/TM-2008/117, February 2009, available at http://info.ornl.gov/sites/publications/Files/Pub12154.pdf

${ }_{\S}^{\S}$ Federal Register Vol. 78 (98), Tuesday, May 21, 2013
} 
CMB approach was used to compute fuel economy, thereby allowing a straightforward evaluation of the impact of ethanol content on fuel economy. However, if an ethanol-containing fuel is to become the new certification fuel for light-duty vehicles, consistent application of the CFR equation needs to be considered for the benefit of manufacturers' CAFE compliance.

Analysis of city cycle Federal Test Procedure (FTP) fuel economy test results and fuel analyses from the catalyst durability study indicates that the average R-factor for modern vehicles is very close to unity at about $0.94 \pm 0.04$. This result is very similar to the results of the 1993 Auto/Oil test program. ${ }^{*}$ Future work should examine other drive cycles, and advanced vehicle technologies which may reveal sensitivities to properties other than heating value.

* Albert Hochhauser et al., SAE paper 930138, March 1993. 


\section{BACKGROUND}

The Energy Independence and Security Act of $2007^{*}$ requires significant increases in the nation's use of renewable fuels to meet its transportation energy needs. The law established a renewable fuel standard that requires the nation to use 36 billion gallons of renewable fuel per year in its vehicles by 2022. Given that ethanol is the most widely used renewable fuel in the United States and production is expected to continue to grow over the next several years, ethanol will likely make up a significant portion of the renewable fuels required by the standard. Most of the ethanol used in the United States is blended with gasoline to create E10 — gasoline with up to 10\% ethanol. In 2010 and 2011 the EPA approved the use of E15 in 2001 and newer light-duty vehicles ${ }^{\dagger, \ddagger}$ citing a number of studies, including the DOE catalyst durability study. ${ }^{\S}$ (Appendix A lists a full bibliography of related intermediate ethanol blend studies.)

During the normal course of the catalyst durability study, vehicles were periodically tested for emissions and fuel economy on the light-duty Federal Test Procedure, or FTP-75. ${ }^{* *}$ As such, a large number of fuel economy test results on a range of fuels are available for analysis. Details on vehicle selection, test protocol, and fuels used can be found in the catalyst durability study final report.

This report describes a preliminary analysis of the fuel economy data from the catalyst durability study, to determine the proper value for the $\mathrm{R}$ factor which is called out in the Code of Federal Regulations (CFR) for computing vehicle fuel economy on the certification cycle. The fuel economy equation that is specified in CFR for gasoline-fuelled vehicles is based on a carbon mass balance (CMB) approach to determine the amount of fuel consumed during the test by measuring the carbon-bearing emissions that are produced; however, it also incorporates a scaling factor ( $\mathrm{R}$ factor) based on the net heating value of the fuel and the sensitivity of fuel economy to changes in the heating value. ${ }^{\dagger \dagger, \text { 㧊 }}$ The impact of the R factor is a fixed ratio in the resultant fuel economy that is dependent upon fuel properties other than those required for a typical CMB calculation. This equation was put in place in 1988 to correct for differences between certification fuels to address corporate average fuel economy (CAFE) credit issues associated with fuel property variations. The algorithm adjusts the calculated fuel economy to compute what would have been measured had the 1975 certification fuel been used for the test. The $\mathrm{R}$ factor was defined to be 0.6 based on tests using 1980s vehicles. Since that time, the Auto/Oil test program has established that the $\mathrm{R}$ factor for 1990s vehicles is higher (about 0.93). ${ }^{\S}$ More recently EPA analyzed the EPAct/V2/E-89 dataset $^{* * *}$ to compute the $\mathrm{R}$ factor, resulting in an average of 0.82 to $0.86 .{ }^{\dagger \dagger \dagger}$ It is important to note that

\footnotetext{
${ }^{*}$ H.R. $6\left(110^{\text {th }}\right)$ : Energy Independece and Security Act of 2007, 12/19/2007, available at: http://www.govtrack.us/congress/bills/110/hr6/text

${ }^{\dagger}$ Federal Register, Vol. 75(213), Thursday, November 4, 2010, Notices.

${ }^{\ddagger}$ Federal Register, Vol. 76(17), Wednesday, January 26, 2011, Notices.

$\S$ West, Brian H., Scott Sluder, Keith Knoll, John Orban, Jingyu Feng, Intermediate Ethanol Blends Catalyst Durability Program, ORNL/TM-2011/234, February 2012, available at http://info.ornl.gov/sites/publications/Files/Pub31271.pdf

** The FTP-75 is the basis of light duty vehicle "city” fuel economy. See http://www.epa.gov/nvfel/testing/dynamometer.htm

${ }^{+\dagger}$ Federal Register Vol. 51(206), Friday, October 24, 1986, pp. 37844-37852.

\#40 CFR Pt. 600.

${ }^{\S}$ Albert Hochhauser et al., "Fuel Composition Effects on Automotive Fuel Economy-Auto/Oil Air Quality Improvement Research Program,” SAE paper 930138, SAE International, Warrendale, Pennsylvania, March 1993.

**** "EPAct/V2/E-89: Assessing the Effect of Five Gasoline Properties on Exhaust Emissions from Light-Duty Vehicles Certified to Tier 2 Standards, Final Report on Program Design and Data Collection”, Report Number EPA-420-R-13-004, March 2013

${ }^{++\dagger}$ Aron Butler, David Good, Arvin Mitcham, “Analysis of the Effects of Changing Fuel Properties on the EPA Fuel Economy Equation and R-Factor,” Memorandum to Tier 3 Docket \#EPA-H!-OAR-2011-0135, available at http://www.regulations.gov/\#!documentDetail;D=EPA-HQ-OAR-2011-0135-0604
} 
the EPAct/V2/E89 test program used the LA92 test cycle, a cycle known to contain more aggressive accelerations than the FTP.

Calculating modern vehicle fuel economy with the existing CFR equation with an $\mathrm{R}$ factor of 0.6 when ethanol blends are used produces significant errors. For the catalyst durability program, a straightforward CMB approach was used to compute fuel economy, thereby allowing a straightforward evaluation of the impact of ethanol content on fuel economy. However, if an ethanol-containing fuel is to become the new certification fuel for light-duty vehicles, consistent application of the CFR equation needs to be considered for the benefit of manufacturers' CAFE compliance. The R factor is defined in more detail in Section 2 of this report.

To date, EPA has only required emissions and fuel economy testing of gasoline-fuelled vehicles with a certification gasoline that does not contain ethanol. However in 2013 EPA issued a Proposed Rule seeking comment on the establishment of an emissions certification fuel containing ethanol, such as E10 or E15. ${ }^{\dagger}$ The use of ethanol-containing fuel for certification will likely require changes to the Code of Federal Regulations (CFR), to allow for proper calculation of CAFE fuel economy.

\footnotetext{
* Keith Knoll, Brian West, Wendy Clark, Ronald Graves, John Orban, Steve Przesmitzki, Timothy Theiss, Effects of Intermediate Ethanol Blends on Legacy Vehicles and Small Non-Road Engines, Report 1-Updated, NREL/TP-540-43543, ORNL/TM-2008/117, February 2009, available at http://info.ornl.gov/sites/publications/Files/Pub12154.pdf

${ }^{\dagger}$ Federal Register Vol. 78 (98), Tuesday, May 21, 2013
} 


\section{APPROACH}

\subsection{VEHICLE SELECTION}

Vehicles included in the $\mathrm{R}$ factor analysis described herein are shown in Tables 2.1 and 2.2. A total of 14 Tier 2 and 4 Tier 1/NLEV vehicle models were used for this analysis.

Table 2.1. Tier 2 vehicle models in the $\mathbf{R}$ factor analysis

\begin{tabular}{|c|c|c|c|c|c|c|}
\hline $\begin{array}{l}\text { Test } \\
\text { site }\end{array}$ & $\begin{array}{c}\text { Model } \\
\text { year }\end{array}$ & Vehicle model & $\begin{array}{l}\text { Engine family } \\
\text { number }^{a}\end{array}$ & $\begin{array}{c}\text { Engine } \\
\text { displacement } \\
\text { (liters) }\end{array}$ & $\begin{array}{c}\text { Engine } \\
\text { configuration }\end{array}$ & $\begin{array}{c}\text { Tier } 2 \\
\text { emissions } \\
\text { standard }\end{array}$ \\
\hline \multirow{7}{*}{ 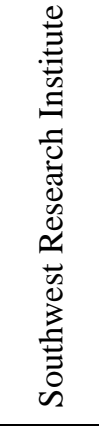 } & 2007 & Honda Accord & 7HNXV02.4KKC & 2.4 & I4 & Bin 5 \\
\hline & 2006 & Chevrolet Silverado & 6GMXT05.3379 & 5.3 & V8 & Bin 8 \\
\hline & 2008 & Nissan Altima & 8NSXV02.5G5A & 2.5 & $\mathrm{I} 4$ & Bin 5 \\
\hline & 2008 & Ford Taurus & 8FMXV03.5VEP & 3.5 & V6 & Bin 5 \\
\hline & 2007 & Dodge Caravan & 7CRXT03.8NEO & 3.8 & V6 & Bin 5 \\
\hline & 2006 & Chevrolet Cobalt & 6GMXV02.4029 & 2.4 & $\mathrm{I} 4$ & Bin 5 \\
\hline & 2007 & Dodge Caliber & 7CRXB02.4MES & 2.4 & I4 & Bin 5 \\
\hline \multirow{7}{*}{ 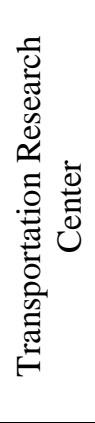 } & 2009 & Jeep Liberty & 9CRXT03.74PO & 3.7 & V6 & Bin 5 \\
\hline & 2009 & Ford Explorer & 9FMXT04.03DC & 4.0 & V6 & Bin 4 \\
\hline & 2009 & Honda Civic & 9HNXV01.8XB9 & 1.8 & $\mathrm{I} 4$ & Bin 5 \\
\hline & 2009 & Toyota Corolla & 9TYXV01.8BEA & 1.8 & I4 & Bin 5 \\
\hline & 2005 & Toyota Tundra & 5TYXT04.0NEM & 4.0 & V6 & Bin 5 \\
\hline & 2006 & Chevrolet Impala & 6GMXV03.9048 & 3.9 & V6 & Bin 5 \\
\hline & 2005 & Ford F150 & 5FMXT05.4R17 & 5.4 & V8 & Bin 8 \\
\hline
\end{tabular}

a“Engine family" and "test group” are often used interchangeably.

Table 2.2. Non-Tier-2 vehicle models in the $R$ factor analysis

\begin{tabular}{|c|c|c|c|c|c|c|}
\hline $\begin{array}{l}\text { Test } \\
\text { site }^{a}\end{array}$ & $\begin{array}{l}\text { Model } \\
\text { year }\end{array}$ & Vehicle model & $\begin{array}{l}\text { Engine family } \\
\text { number }\end{array}$ & $\begin{array}{c}\begin{array}{c}\text { Engine } \\
\text { displacement } \\
\text { (liters) }\end{array} \\
\end{array}$ & $\begin{array}{c}\text { Engine } \\
\text { configuration }\end{array}$ & $\begin{array}{l}\text { Emissions } \\
\text { standard }^{b}\end{array}$ \\
\hline \multirow{2}{*}{$\begin{array}{l}\vec{p} \\
\frac{1}{3} \\
\omega\end{array}$} & 2002 & Nissan Frontier & 2NSXT02.4C4B ${ }^{c}$ & 2.4 & I4 & NLEV/LDT1 \\
\hline & 2002 & Dodge Durango & 2CRXT04.75B0 & 4.7 & V8 & Tier 1/LDT3 \\
\hline \multirow{2}{*}{ 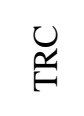 } & 2003 & Toyota Camry & 3TYXV02.4HHA & 2.4 & I4 & ULEV \\
\hline & 2003 & Ford Taurus & 3FMXV03.0VF3 & 3.0 & V6 & NLEV \\
\hline
\end{tabular}

${ }^{a}$ SwRI $=$ Southwest Research Institute, TRC $=$ Transportation Research Center Inc.

${ }^{b}$ LDT = light-duty truck, ULEV = ultralow emission vehicle, NLEV = National Low Emission Vehicle (Program). LDT1-LDT3 are light truck emissions categories based on vehicle weight. (See http://www.epa.gov/otaq/standards/light-duty/index.htm)

c "Engine family" on Frontier vehicles did not exactly match the EPA database for the 2002 Frontier (see ORNL/TM-2011/234). 


\subsection{VEHICLE AGING AND TEST PROTOCOL}

Vehicles were acquired in matched sets of three or four vehicles. Matched vehicles had identical engine and transmission configuration, engine controller software, tire size, etc. Each vehicle of a set was dedicated to a specific ethanol blend for aging and emissions testing (including one dedicated to ethanolfree gasoline, or E0). Thus for a matched set of four vehicles, one vehicle was dedicated to E0, one to E10, one to E15, and one to E20. For sets of three matched vehicles, E10 was omitted. Vehicles were emissions tested at the start, middle, and end of the program, and aged on a dedicated fuel in between emissions tests. At each emissions test interval each vehicle was tested on E0 fuel and its designated ethanol blend. At each fuel change, a rigorous fuel change and adaptation protocol was followed. Details on the vehicle aging and test protocol are provided in the catalyst durability program final report.

\subsubsection{Aging Fuels}

Aging was conducted by assigning one vehicle of each set to a fuel with a given ethanol concentration (including E0). Because the vehicles would be accruing considerable mileage and because of the relatively large number of vehicles involved in the program, it was necessary to use splash blended fuels for the aging program to reduce the fuel cost to a manageable level. For this purpose, top-tier retail gasoline ${ }^{\dagger}$ that did not contain ethanol was purchased locally and splash blended to produce the necessary ethanol-containing blends. SwRI acquired top-tier gasoline and splash blended it with ASTM D4806 denatured ethanol ${ }^{\ddagger}$ onsite to produce the $10 \%, 15 \%$, and $20 \%$ ethanol blends required. TRC procured the ethanol blends from the terminal, pre-blended to the desired levels. The aging fuels were termed RE0, RE10, RE15, and RE20 to convey that they were blended using retail gasoline and to denote the nominal ethanol content of each fuel.

\subsubsection{Emissions Test Fuels}

The emissions test fuels were splash blends using emissions certification gasoline and ASTM D4806 denatured ethanol. TRC sourced the emissions fuel components (UTG-96 Federal Certification Gasoline and denatured ethanol) from Chevron-Phillips Specialty Chemical Company. SwRI obtained Haltermann EEE certification gasoline and ASTM D4806 denatured ethanol. The fuels were splash blended on-site at each test laboratory and subsequently analyzed to provide the fuel properties needed to support data analysis. Additional fuel analyses beyond those required for emissions tests were also performed on selected samples. These emissions test fuels were termed E0, E10, E15, and E20 to denote that they were different from the retail fuels used for vehicle aging (RE0, for example). As with the aging fuels, the octane number, RVP, and other properties of the emissions fuels varied with the ethanol content as a consequence of the splash blended nature of the fuels. Because all emissions tests were conducted at a nominal $25^{\circ} \mathrm{C}$ and because tracking emissions changes over time was the primary program objective, the use of splash blends in lieu of match blends was not expected to impact the results. When using match blends, certain fuel properties such as volatility and octane can be tailored to match the desired ethanol blend level. When splash blends are used, it is understood that properties such as volatility and octane will vary with ethanol content, ${ }^{\S, * *}$ but it was judged by the project leadership that these variations would not

\footnotetext{
* West, et al., Intermediate Ethanol Blends Catalyst Durability Program, ORNL/TM-2011/234,February 2012.

${ }^{\dagger}$ Top-tier gasoline contains more deposit-control additives than the EPA minimum requirements (http://www.toptiergas.com/).

${ }^{\ddagger}$ ASTM D4806 - Standard Specification for Denatured Fuel Ethanol for Blending with Gasolines for Use as Automotive SparkIgnition Engine Fuel

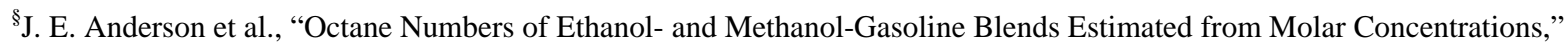
Energy Fuels 2010, 24, pp. 6576-6585.

*** American Petroleum Institute, Determination of the Potential Property Ranges of Mid-Level Ethanol Blends, Final Report, April 2010.
} 
impact the results. ${ }^{*}$ In addition, acquisition of match blends would have presented unreasonable cost and time delay burdens to the program. Some of the carbon mass fraction and heating value results came into question during the $\mathrm{R}$ factor analysis. Because the $\mathrm{R}$ factor is very sensitive to fuel properties, some adjustments were made to some fuel properties, as described in the next section.

Table 2.3 shows the relevant fuel properties for the emissions test fuels at SwRI (note that only the first five SwRI vehicle sets included E10). Each vehicle was tested with the same E0 or ethanol blend at each emissions testing interval. Table 2.4 shows the same properties for the vehicles at TRC. Because there were multiple batches of ethanol blends, Table 2.4 shows fuel properties for start-of-test, midlife test, and end-of-test. Some property values were adjusted for the R factor analysis, as described in the next two sections. All heating values were calculated from D240 (BTU/lb) and density.

Table 2.3. Emissions test fuel properties at SwRI. Shaded cells denote adjusted carbon mass fraction as discussed in section 2.2.3.

\begin{tabular}{|c|c|c|c|c|c|c|c|c|c|c|c|c|}
\hline \multirow[b]{2}{*}{ Vehicle } & \multicolumn{3}{|c|}{ EO Fuel } & \multicolumn{3}{|c|}{ E10 Fuel } & \multicolumn{3}{|c|}{ E15 Fuel } & \multicolumn{3}{|c|}{ E20 Fuel } \\
\hline & $\begin{array}{c}\text { Carbon } \\
\text { Fraction } \\
\text { ASTM } \\
\text { D5291 } \\
\end{array}$ & $\begin{array}{c}\text { Density } \\
\text { (g/cc) } \\
\text { ASTM } \\
\text { D4052 }\end{array}$ & $\begin{array}{c}\text { LHV } \\
\text { (BTU/gal) }\end{array}$ & $\begin{array}{c}\text { Carbon } \\
\text { Fraction } \\
\text { ASTM } \\
\text { D5291 } \\
\end{array}$ & $\begin{array}{c}\text { Density } \\
\text { (g/cc) } \\
\text { ASTM } \\
\text { D4052 }\end{array}$ & $\begin{array}{c}\text { LHV } \\
\text { (BTU/gal) }\end{array}$ & $\begin{array}{c}\text { Carbon } \\
\text { Fraction } \\
\text { ASTM } \\
\text { D5291 } \\
\end{array}$ & $\begin{array}{c}\text { Density } \\
\text { (g/cc) } \\
\text { ASTM } \\
\text { D4052 }\end{array}$ & $\begin{array}{c}\text { LHV } \\
\text { (BTU/gal) }\end{array}$ & $\begin{array}{c}\text { Carbon } \\
\text { Fraction } \\
\text { ASTM } \\
\text { D5291 } \\
\end{array}$ & $\begin{array}{l}\text { Density } \\
\text { (g/cc) } \\
\text { ASTM } \\
\text { D4052 }\end{array}$ & $\begin{array}{c}\text { LHV } \\
\text { (BTU/gal) }\end{array}$ \\
\hline 2007 Accord & 0.869 & 0.744 & 115,495 & 0.831 & 0.748 & 111,491 & 0.815 & 0.752 & 109,656 & 0.792 & 0.754 & 106,727 \\
\hline \begin{tabular}{|l}
2006 Silverado \\
2008 Altima \\
\end{tabular} & 0.869 & 0.743 & 115,138 & 0.829 & 0.751 & 111,296 & 0.812 & 0.751 & 108,849 & 0.794 & 0.752 & 107,213 \\
\hline \begin{tabular}{|l|}
2008 Taurus \\
2007 Caravan \\
\end{tabular} & 0.878 & 0.742 & 116,328 & 0.832 & 0.748 & 111,707 & 0.817 & 0.751 & 109,844 & 0.795 & 0.752 & 107,269 \\
\hline \begin{tabular}{|l|}
2006 Cobalt \\
2007 Caliber \\
2002 Frontier \\
\end{tabular} & 0.866 & 0.744 & 114,784 & Vehicl & not test & on E10 & 0.813 & 0.751 & 109,483 & 0.793 & 0.753 & 107,330 \\
\hline 2002 Durango & 0.866 & 0.743 & 115,083 & & & & 0.811 & 0.752 & 108,782 & 0.798 & 0.753 & 107,549 \\
\hline
\end{tabular}

\subsubsection{Adjustment of Carbon Weight Fraction for Some Fuels}

The Carbon weight fraction of gasoline range fuels is normally determined by the test protocol prescribed by ASTM D5291. The volatility of gasoline and gasoline-ethanol blends can sometimes cause a loss of a small portion of the sample during the execution of the ASTM D5291 test that determines the carbon, hydrogen, and nitrogen weight fractions of the fuel. In some cases at SwRI, incomplete recovery was observed during this test, and in these cases, the carbon weight fraction was adjusted during completion of the fuel economy calculations for the FTP results. The adjustment changes the carbon weight fraction in the third decimal place (e.g., from 0.863 to 0.866 ). This adjustment was accomplished by summing the carbon and hydrogen weight fractions. In the event that the sum was less than $100 \%$ for an E0 fuel, a multiplication factor was computed by dividing 100 by the sum. For example, if the carbon and hydrogen weight fractions summed to $99.3 \%$, a factor of 1.007 was computed by dividing 100 by 99.3 . The carbon and hydrogen weight fractions were then both multiplied by 1.007 prior to their use in calculating fuel economy results for the FTP tests. In cases where the fuel also contained oxygen due to ethanol blending, the oxygen content was accepted as accurate and subtracted from 100 and the result divided by the sum of the carbon and hydrogen weight fractions to calculate the multiplication factor to be used to adjust the carbon and hydrogen weight fractions. Oxygen content was determined by ASTM D5599 for the SwRI fuels (and by D5622 for the TRC fuels). This procedure results in the sum of carbon, hydrogen, nitrogen, and oxygen weight fractions being $100 \%$ for each fuel and corrects the D5291 results when a loss of some

* West, et al., Intermediate Ethanol Blends Catalyst Durability Program, ORNL/TM-2011/234, February 2012. 
of the sample has occurred. This method inherently assumes that the speciation of the fuel sample did not change as a result of the mass loss. This adjustment was done 12 times for the SwRI fuels shown in Table 2.3.

\subsubsection{Adjustment of Fuel Heating Values for Some Fuels}

During analysis of the data, three heating value results from the TRC test fuels were noted to be considerably lower than expected, falling well below a line drawn through the data as shown in Figure 1. The three red data points are the results that were noted to appear inconsistent with other fuels. Since all of the ethanol-blended fuels were blended from the same batch of E0, the remaining data points (shown as blue points) were used to establish a best-fit linear correlation between heating value and fuel oxygen content. The suspect heating value results were re-computed using this relationship, resulting in increases in the heating value for these three fuels. The circles show the heating values that were used in calculations to determine $\mathrm{R}$ factors. For heating values that were not adjusted, the circles overlay the blue data points. For heating values that were adjusted, the circles appear vertically separated from the red data points, indicating the amount the heating value was adjusted (adjustments ranged from 63 to 194 $\mathrm{BTU} / \mathrm{lb}_{\mathrm{m}}$, or 0.4 to $\left.1.1 \%\right)$.

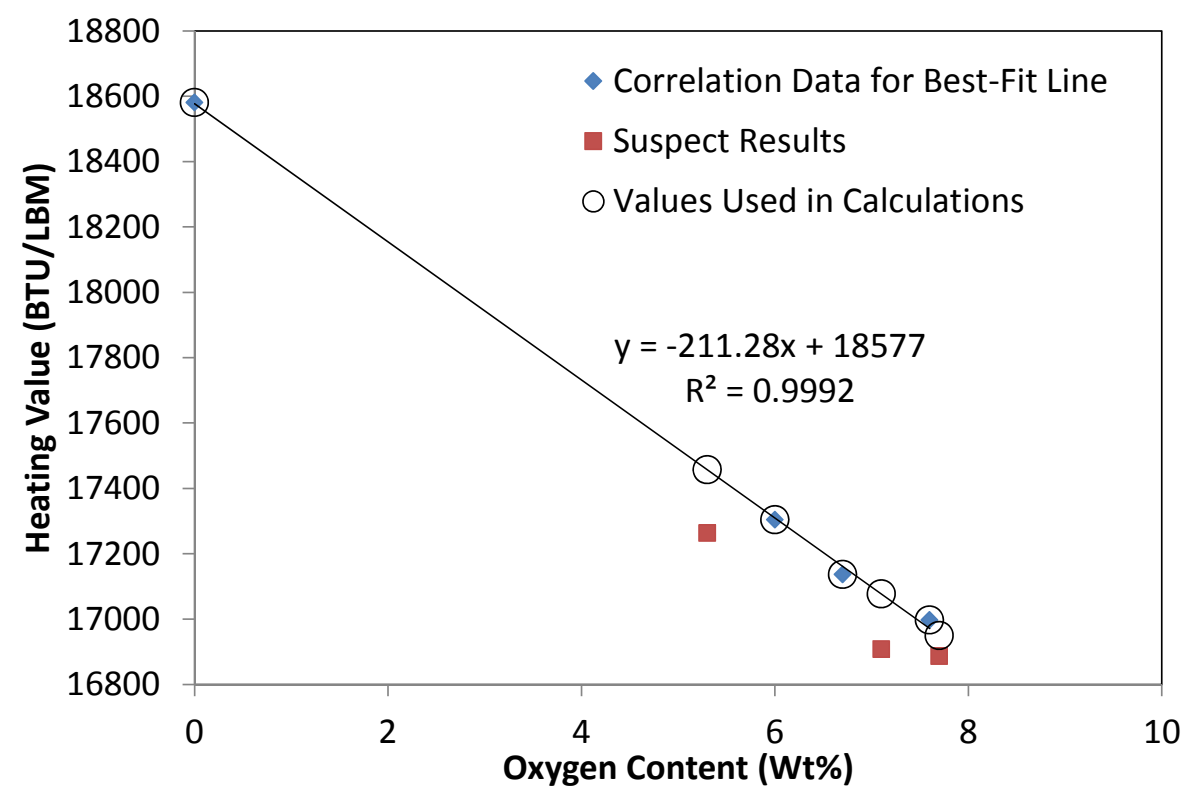

Figure 1. Heating value versus oxygen content for the TRC test fuels. 
Table 2.4. Emissions test fuel properties at TRC. Shaded cells denote adjusted heating values as discussed in section 2.2.4.

\begin{tabular}{|c|c|c|c|c|c|c|c|c|c|}
\hline \multicolumn{10}{|c|}{ Start of Test } \\
\hline \multirow[b]{2}{*}{ Vehicle } & \multicolumn{3}{|c|}{ EO Fuel } & \multicolumn{3}{|c|}{ E15 Fuel } & \multicolumn{3}{|c|}{ E20 Fuel } \\
\hline & $\begin{array}{c}\text { Carbon } \\
\text { Fraction } \\
\text { ASTM } \\
\text { D5291 }\end{array}$ & $\begin{array}{c}\text { Density } \\
\text { (g/cc) } \\
\text { ASTM } \\
\text { D4052 }\end{array}$ & $\begin{array}{c}\text { LHV } \\
\text { (BTU/gal) }\end{array}$ & $\begin{array}{c}\text { Carbon } \\
\text { Fraction } \\
\text { ASTM } \\
\text { D5291 }\end{array}$ & $\begin{array}{c}\text { Density } \\
\text { (g/cc) } \\
\text { ASTM } \\
\text { D4052 }\end{array}$ & $\begin{array}{c}\text { LHV } \\
\text { (BTU/gal) }\end{array}$ & $\begin{array}{c}\text { Carbon } \\
\text { Fraction } \\
\text { ASTM } \\
\text { D5291 }\end{array}$ & $\begin{array}{c}\text { Density } \\
\text { (g/cc) } \\
\text { ASTM } \\
\text { D4052 }\end{array}$ & $\begin{array}{c}\text { LHV } \\
\text { (BTU/gal) }\end{array}$ \\
\hline \begin{tabular}{|l|}
2009 Civic \\
2009 Explorer \\
2009 Corolla \\
2009 Liberty
\end{tabular} & \multirow{3}{*}{0.872} & \multirow{3}{*}{0.743} & \multirow{3}{*}{115,205} & \multirow{3}{*}{0.809} & \multirow{3}{*}{0.751} & \multirow{3}{*}{108,441} & 0.801 & 0.753 & 107,680 \\
\hline $\begin{array}{l}2005 \text { Tundra } \\
2006 \text { Impala } \\
2005 \text { F150 }\end{array}$ & & & & & & & 0.792 & 0.754 & 106,648 \\
\hline$\frac{2003 \text { Camry }}{2003 \text { Taurus }}$ & & & & & & & 0.792 & 0.752 & 106,659 \\
\hline
\end{tabular}

\begin{tabular}{|c|c|c|c|c|c|c|c|c|c|}
\hline \multicolumn{10}{|c|}{ Midlife Test } \\
\hline \multirow[b]{2}{*}{ Vehicle } & \multicolumn{3}{|c|}{ EO Fuel } & \multicolumn{3}{|c|}{ E15 Fuel } & \multicolumn{3}{|c|}{ E20 Fuel } \\
\hline & $\begin{array}{c}\text { Carbon } \\
\text { Fraction } \\
\text { ASTM } \\
\text { D5291 }\end{array}$ & $\begin{array}{c}\text { Density } \\
\text { (g/cc) } \\
\text { ASTM } \\
\text { D4052 }\end{array}$ & $\begin{array}{c}\text { LHV } \\
\text { (BTU/gal) }\end{array}$ & $\begin{array}{c}\text { Carbon } \\
\text { Fraction } \\
\text { ASTM } \\
\text { D5291 }\end{array}$ & $\begin{array}{l}\text { Density } \\
\text { (g/cc) } \\
\text { ASTM } \\
\text { D4052 }\end{array}$ & $\begin{array}{c}\text { LHV } \\
\text { (BTU/gal) }\end{array}$ & $\begin{array}{c}\text { Carbon } \\
\text { Fraction } \\
\text { ASTM } \\
\text { D5291 }\end{array}$ & $\begin{array}{c}\text { Density } \\
\text { (g/cc) } \\
\text { ASTM } \\
\text { D4052 }\end{array}$ & $\begin{array}{c}\text { LHV } \\
\text { (BTU/gal) }\end{array}$ \\
\hline 2009 Civic & \multirow{8}{*}{0.872} & \multirow{8}{*}{0.743} & \multirow{8}{*}{115,205} & \multirow{7}{*}{0.809} & \multirow{7}{*}{0.751} & \multirow{7}{*}{108,441} & \multirow{3}{*}{0.792} & \multirow{3}{*}{0.754} & \multirow{3}{*}{106,648} \\
\hline 2009 Explorer & & & & & & & & & \\
\hline \begin{tabular}{|l|}
2009 Corolla \\
2009 Liberty
\end{tabular} & & & & & & & & & \\
\hline 2005 Tundra & & & & & & & & \multirow{3}{*}{0.752} & \multirow{3}{*}{106,659} \\
\hline 2006 Impala & & & & & & & 0.792 & & \\
\hline 2005 F150 & & & & & & & & & \\
\hline 2003 Camry & & & & & & & 0.795 & 0.752 & 106,910 \\
\hline 2003 Taurus & & & & 0.813 & 0.749 & 109,111 & 0.797 & 0.752 & 107,161 \\
\hline
\end{tabular}

\begin{tabular}{|c|c|c|c|c|c|c|c|c|c|}
\hline \multicolumn{10}{|c|}{ End of Test } \\
\hline \multirow[b]{2}{*}{ Vehicle } & \multicolumn{3}{|c|}{ EO Fuel } & \multicolumn{3}{|c|}{ E15 Fuel } & \multicolumn{3}{|c|}{ E20 Fuel } \\
\hline & 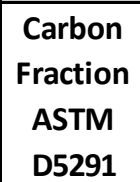 & $\begin{array}{c}\text { Density } \\
\text { (g/cc) } \\
\text { ASTM } \\
\text { D4052 }\end{array}$ & $\begin{array}{c}\text { LHV } \\
\text { (BTU/gal) }\end{array}$ & $\begin{array}{c}\text { Carbon } \\
\text { Fraction } \\
\text { ASTM } \\
\text { D5291 }\end{array}$ & $\begin{array}{c}\text { Density } \\
\text { (g/cc) } \\
\text { ASTM } \\
\text { D4052 }\end{array}$ & $\begin{array}{c}\text { LHV } \\
\text { (BTU/gal) }\end{array}$ & $\begin{array}{c}\text { Carbon } \\
\text { Fraction } \\
\text { ASTM } \\
\text { D5291 }\end{array}$ & $\begin{array}{c}\text { Density } \\
\text { (g/cc) } \\
\text { ASTM } \\
\text { D4052 }\end{array}$ & $\begin{array}{c}\text { LHV } \\
\text { (BTU/gal) }\end{array}$ \\
\hline$\frac{2009 \text { Civic }}{2009 \text { Explorer }}$ & \multirow{4}{*}{0.872} & \multirow{4}{*}{0.743} & \multirow{4}{*}{115,205} & 0.809 & 0.751 & 108,441 & 0.792 & 0.752 & 106,659 \\
\hline 2009 Corolla & & & & \multirow{3}{*}{0.813} & \multirow{3}{*}{0.749} & \multirow{3}{*}{109,111} & \multirow{3}{*}{0.797} & \multirow{3}{*}{0.752} & \multirow{3}{*}{107,161} \\
\hline $\begin{array}{l}2005 \text { Tundra } \\
2006 \text { Impala }\end{array}$ & & & & & & & & & \\
\hline $\begin{array}{l}\frac{2005 \text { F150 }}{2003 \text { Camry }} \\
2003 \text { Taurus }\end{array}$ & & & & & & & & & \\
\hline
\end{tabular}




\subsection{R-Factor Analysis Approach}

\subsubsection{R Factor Definition}

As discussed previously, the $\mathrm{R}$ factor is a value that describes change in fuel economy that accompanies a change in the volumetric heating value of the fuel being used. For example, when ethanol is blended with gasoline, the heating value of the blend is reduced compared with the gasoline before blending. This reduction is a result of the presence of ethanol, which has a lower volumetric heating value than gasoline. The $\mathrm{R}$ factor is defined according to the following equation.

$$
R=\frac{\left(\frac{V O L F E i}{V O L F E r}\right)-1}{\left(\frac{V O L H V i}{V O L H V r}\right)-1}
$$

VOLFE is the volumetric fuel economy result in miles per gallon for either the test fuel (subscript i) or the reference fuel (subscript r), and VOLHV is the volumetric heating value for the fuels in BTU per gallon, using the same subscripts as for the volumetric fuel economy. Using this form, $\mathrm{R}$ can also be expressed as the percent change in volumetric fuel economy using a test fuel compared to a result with a reference fuel divided by the percent change in the volumetric heating value of the test fuel compared to the volumetric heating value of the reference fuel.

\subsubsection{R Factor Determination}

The fuel economy data were analyzed for each vehicle that was tested using both a fuel that did not contain ethanol and a fuel that was blended with ethanol. During each emissions test interval for each vehicle, the average fuel economy with E0 was calculated and compared with the average fuel economy for the same vehicle tested using an ethanol blended fuel. As an example, consider the determination of $\mathrm{R}$ for a 2009 Ford Explorer, tested at the start-of-test emissions interval. Two such vehicles were tested using an ethanol-blended fuel: one using E15 and the other using E20. The average fuel economy for the E15 vehicle when tested using E0 and when tested using E15 was determined. These data were then used to compute an R value for the E15 2009 Ford Explorer at the start-of-test emissions interval. Similarly, the average fuel economy data were computed for the E20 vehicle and an independent R value computed for this vehicle. In this way, vehicle-to-vehicle variations in baseline fuel economy using E0 were removed from the analysis. Similarly, the R values were assessed for these vehicles at the other emissions test intervals, which removed any affect of vehicle aging on the baseline fuel economy from the $\mathrm{R}$ factor analysis. This approach was repeated for each vehicle and each emissions test interval.

Following determination of the individual $\mathrm{R}$ factors for each vehicle at each emissions test interval, the $\mathrm{R}$ factors were pooled to determine characteristic average values for different vehicle groups. 


\section{RESULTS}

\subsection{R Factor Values}

\subsubsection{Vehicle-Specific R Factors}

The $\mathrm{R}$ factors that were computed for each vehicle model were averaged to produce an overall average $\mathrm{R}$ factor for that model. Because in some cases 2 vehicles (E15 and E20) or 3 vehicles (E10, E15, and E20) were tested at each of three emissions test intervals, a maximum of 9, and in most cases only $6 \mathrm{R}$ factor values could be pooled for each vehicle. As such, the confidence intervals for the vehicle-specific $\mathrm{R}$ factors are relatively large. The vehicle-specific $\mathrm{R}$ factors are shown in Figure 2. Though the average values show considerable variation, many of the $95 \%$ confidence intervals overlap, indicating that much of the variation may be explained by test-to-test variability. The $95 \%$ confidence intervals reported herein are calculated based on the scatter in the fuel economy results. Additionally, there is uncertainty present in the ASTM results for heating value, carbon weight fraction, and specific gravity that have not been included in the confidence intervals. Inclusion of these uncertainties would increase the confidence intervals.

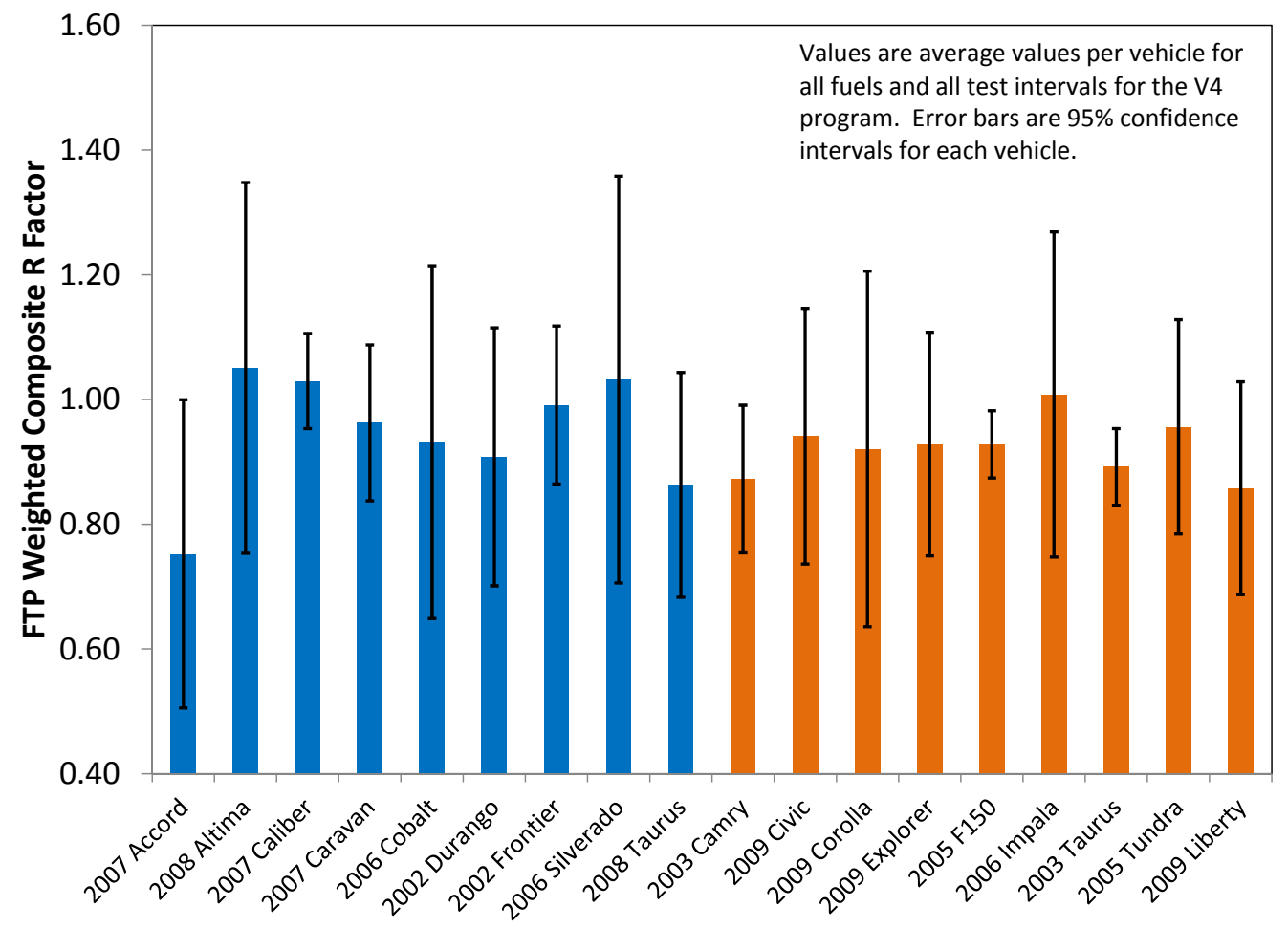

Figure 2. Average $\mathbf{R}$ factor for each vehicle model.

\subsubsection{Average R Factor Values for Fleets}

The data were pooled to analyze the vehicles in four fleets: the SwRI Test Fleet, the TRC Test Fleet, the Total Test Fleet, and the Tier 2 Test Fleet. Additionally, the data were pooled to allow analysis of the impact of fuel ethanol content, if any, on the R factor. These results are shown in Figures 3 and 4. 


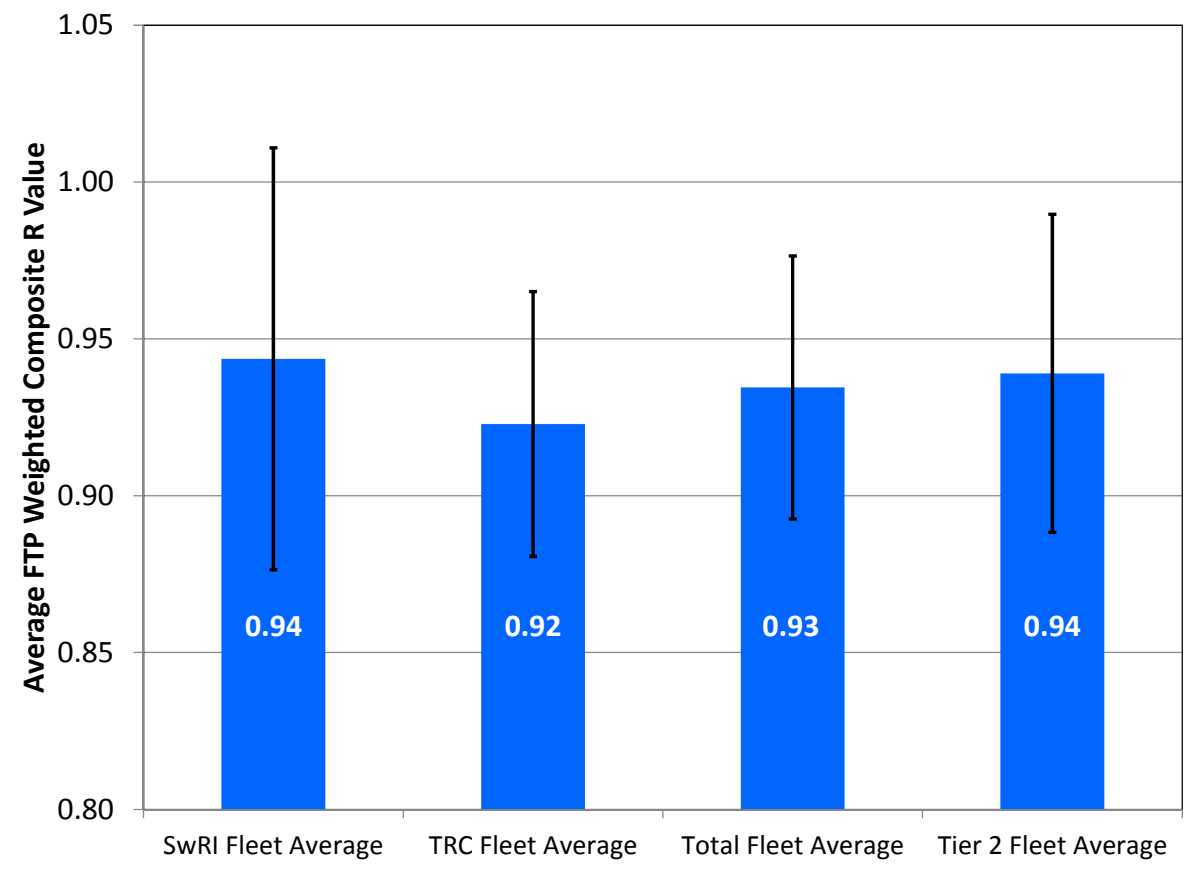

Figure 3. Fleet average $\mathbf{R}$ factor values with $95 \%$ confidence intervals.

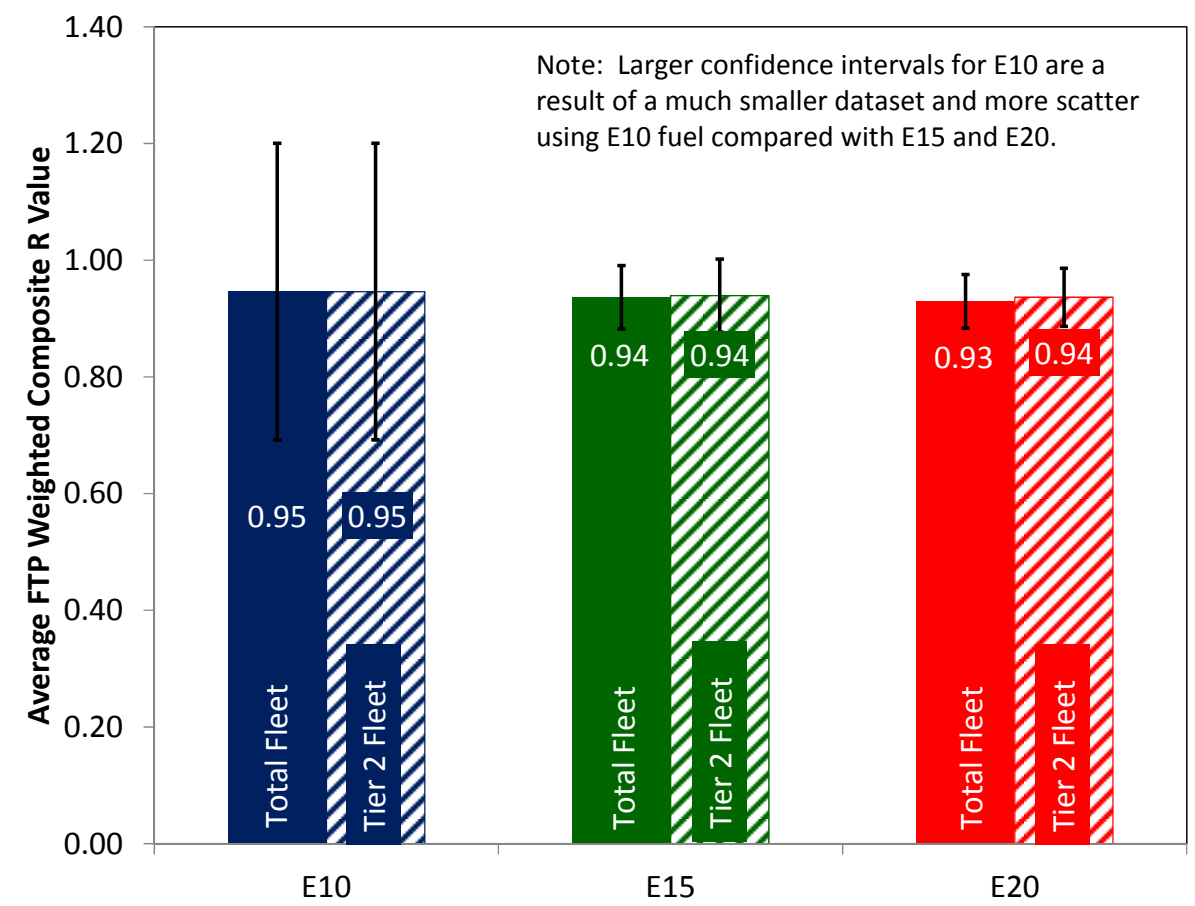

Figure 4. Fleet average $\mathbf{R}$ factor values for ethanol-blended fuels with $95 \%$ confidence intervals.

During the R factor analysis, some of the fuel economy results for the 2007 Honda Accord were questioned. The FTP fuel economy results showed unexpected variability that resulted in R factors that were deemed to be illogical and unrepeatable. No single issue with the data could be firmly established, however. Thus, the fleet average analyses were completed both with the Accord data included, as has previously been presented, and also with the Accord data omitted, as shown in Figures 5 and 6. 
Removing the Honda Accord data had the effect of marginally increasing fleet averages that had previously included the Accord data, and also marginally impacting the 95\% confidence intervals.

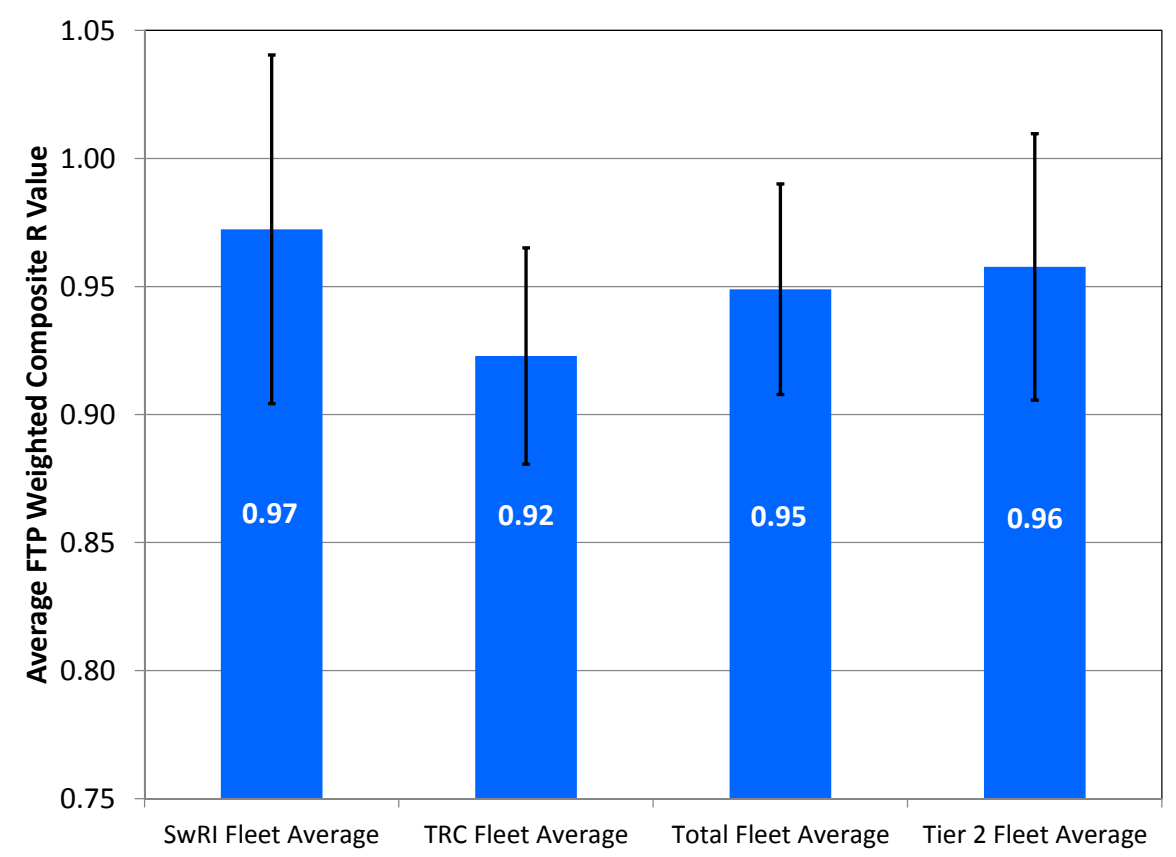

Figure 5. Fleet average $\mathbf{R}$ factor values with 2007 Honda Accord results omitted.

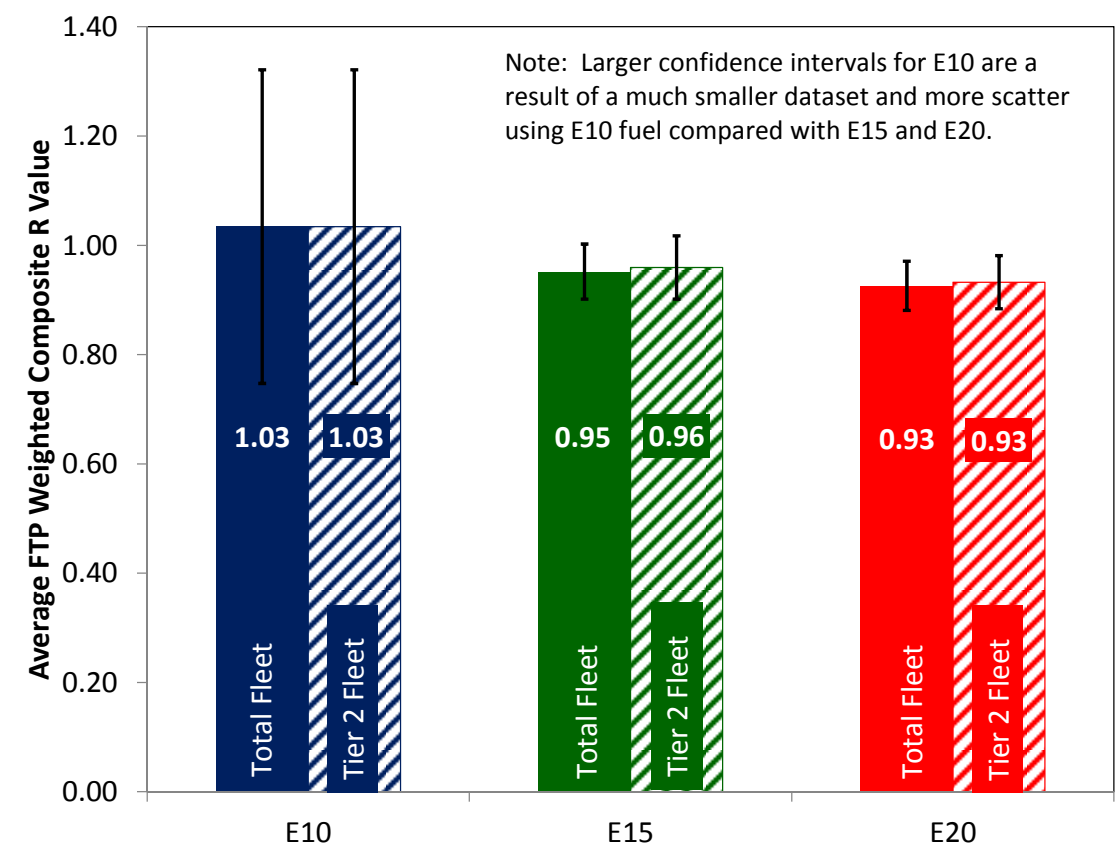

Figure 6. Fleet average $R$ factor values for ethanol-blended fuels with 2007 Honda Accord results omitted. 


\section{CONCLUSIONS}

The calculated R factor for the DOE catalyst durability study vehicles is $0.94 \pm 0.04$ (or $0.96 \pm 0.04$ with one problematic vehicle omitted). Within error limits, these results are the same as those obtained in the 1993 Auto/Oil study. The current factor of 0.6 which is called out in CFR is clearly too low, and a proper factor for modern vehicles is closer to unity, as might be expected from improved air/fuel ratio control common for more modern vehicles. Future work to establish the correct $\mathrm{R}$ factor should consider additional test cycles as well as the potential for high-efficiency technologies that may be impacted by fuel characteristics other than the heating value (the R factor could vary by test cycle and/or with vehicle technology). 
APPENDIX A.

BIBLIOGRAPHY OF INTERMEDIATE ETHANOL BLENDS STUDIES 


\section{APPENDIX A. BIBLIOGRAPHY OF INTERMEDIATE ETHANOL BLENDS STUDIES}

The following reports and websites relate to Intermediate Ethanol Blend Studies supported or partially supported by the Department of Energy since 2007; also listed are relevant EPA and Coordinating Research Council websites. Numerous oral presentations were given throughout the program; these are not listed, however those given at DOE Annual Merit Reviews are included here.

\section{Vehicle-Related Studies (Chronological order)}

1. R. Bechtold, J. F. Thomas, S. P. Huff, J. P. Szybist, T. J. Theiss, B. H. West, M. Goodman, T. A. Timbario, Technical Issues Associated with the Use of Intermediate Ethanol Blends (>E10) in the U.S. Legacy Fleet: Assessment of Prior Studies, ORNL/TM-2007/37, Oak Ridge National Laboratory, August 2007, available at http://info.ornl.gov/sites/publications/files/Pub7767.pdf.

2. Keith Knoll, Brian West, Wendy Clark, Ronald Graves, John Orban, Steve Przesmitzki, Timothy Theiss, Effects of Intermediate Ethanol Blends on Legacy Vehicles and Small Non-Road Engines, Report 1-Updated, NREL/TP-540-43543, ORNL/TM-2008/117, February 2009, available at http://info.ornl.gov/sites/publications/Files/Pub12154.pdf

3. Knoll, Keith, Brian West, Shean Huff, John Thomas, John Orban, Cynthia Cooper, "Effects of Mid-Level Ethanol Blends on Conventional Vehicle Emissions," SAE Technical Paper 2009-012723, 2009, doi:10.4271/2009-01-2723.

4. Brent A. Shoffner, Ryan D. Johnson, Martin J. Heimrich, and Michael D. Lochte, Powertrain Component Inspection from Mid-Level Blends Vehicle Aging Study, ORNL/TM-2011/65, Prepared by Southwest Research Institute for Oak Ridge National Laboratory, November 2010, available at http://info.ornl.gov/sites/publications/files/Pub28733.pdf.

5. C. Scott Sluder and Brian H. West, NMOG Emissions Characterizations and Estimation for Vehicles Using Ethanol-Blended Fuels, ORNL/TM-2011/461, Oak Ridge National Laboratory, October 15, 2011, available at http://info.ornl.gov/sites/publications/Files/Pub33272.pdf.

6. Sluder, C. and West, B., "Limitations and Recommended Practice In the Use of Compression and Leak-Down Tests to Monitor Gradual Engine Degradation," SAE Int. J. Engines 4(3):2767-2777, 2011, doi:10.4271/2011-01-2427.

7. Sluder, C. and West, B., "NMOG Emissions Characterizations and Estimation for Vehicles Using Ethanol-Blended Fuels," SAE Int. J. Fuels Lubr. 5(2):721-732, 2012, doi:10.4271/2012-01-0883.

8. Sluder, C., West, B., and Knoll, K., "Investigating Malfunction Indicator Light Illumination Due to Increased Oxygenate Use in Gasoline," SAE Int. J. Fuels Lubr. 5(3):1360-1371, 2012, doi:10.4271/2012-01-2305.

9. West, Brian H., Scott Sluder, Keith Knoll, John Orban, Jingyu Feng, Intermediate Ethanol Blends Catalyst Durability Program, ORNL/TM-2011/234, February 2012, available at http://info.ornl.gov/sites/publications/Files/Pub31271.pdf

10. Vertin, Keith, Gerard Glinksy, and Aaron Reek, Comparative Emissions Testing of Vehicles Aged on E0, E15, and E20 Fuels, NREL/SR-5400-55778, August 2012, available at http://www.nrel.gov/docs/fy12osti/55778.pdf

11. West, B. and Sluder, C., "Lubricating Oil Consumption on the Standard Road Cycle," SAE Technical Paper 2013-01-0884, 2013, doi:10.4271/2013-01-0884.

12. EPA, NREL, and CRC, EPAct/V2/E-89: Assessing the Effect of Five Gasoline Properties on Exhaust Emissions from Light-Duty Vehicles Certified to Tier 2 Standards. Final Report on Program Design and Data Collection, EPA-420-R-13-004, April 2013, available at http://www.epa.gov/otaq/models/moves/epact.htm 
13. C. Scott Sluder and Brian H. West, Preliminary Examination of Ethanol Fuel Effects on EPA's Rfactor for Vehicle Fuel Economy, ORNL/TM-2013/198, Oak Ridge National Laboratory, June 2013.

14. CRC Reports available at http://crcao.org/news/Mid\%20Level\%20Ethanol\%20program/index.html

\section{Non-Automotive Engines}

15. Keith Knoll, Brian West, Wendy Clark, Ronald Graves, John Orban, Steve Przesmitzki, Timothy Theiss, Effects of Intermediate Ethanol Blends on Legacy Vehicles and Small Non-Road Engines, Report 1-Updated, NREL/TP-540-43543, ORNL/TM-2008/117, February 2009, available at http://info.ornl.gov/sites/publications/Files/Pub12154.pdf (repeated from \#2 above, contains vehicle and SNRE data)

16. Zooubul, George, Mel Cahoon, and Richard Kolb, Volvo Penta 4.3 GL E15 Emissions and Durability Test, NREL/SR-5400-52577, October 2011, available at http://www.nrel.gov/docs/fy12osti/52577.pdf

17. Hilbert, David, High Ethanol Fuel Endurance: A Study of the Effects of Running Gasoline with 15\% Ethanol Concentration in Current Production Outboard Four-Stroke Engines and Conventional Two-Stroke Outboard Marine Engines, NREL/SR-5400-52909, October 2011, available at http://www.nrel.gov/docs/fy12osti/52909.pdf

\section{Materials and Infrastructure}

18. Boyce, Kenneth, J. Thomas Chapin, Dispensing Equipment Testing With Mid-Level Ethanol/Gasoline Test Fluid: Summary Report , Underwriters Laboratories, Inc. report, November 2010, available at http://www.nrel.gov/docs/fy11osti/49187.pdf

19. M. D. Kass, T. J Theiss, C. J. Janke. S. J Pawel, and S. A. Lewis, Sr., Intermediate Ethanol Blends Infrastructure Materials Compatibility Study: Elastomers, Metals, and Sealants, ORNL/TM-2010/326, March 2011, available at http://info.ornl.gov/sites/publications/files/Pub27766.pdf

20. M. D. Kass, T. J Theiss, C. J. Janke. and S. J Pawel, Compatibility Study for Plastic, Elastomeric, and Metallic Fueling Infrastructure Materials Exposed to Aggressive Formulations of Ethanolblended Gasoline, ORNL/TM-2012/88, July 2012 available at http://info.ornl.gov/sites/publications/Files/Pub35074.pdf

21. M. D. Kass, T. J Theiss, C. J. Janke. and S. J Pawel, Analysis of Underground Storage Tanks System Materials to Increased Leak Potential Associated with E15 Fuel, ORNL/TM-2012/182, July 2012 (Report for USEPA Office of Underground Storage Tanks) available at http://info.ornl.gov/sites/publications/Files/Pub36356.pdf

22. M. D. Kass, T. J Theiss, C. J. Janke. S. J Pawel, J. T. Chapin, T. Fabian, K. Boyce and E. Yang, “Elastomer Compatibility to Gasoline Containing Intermediate Levels of Ethanol," Sealing Technology, December 2012, pgs. 7-12

23. EPA website on ethanol compatibility: http://www.epa.gov/oust/altfuels/ethcompat.htm 


\section{DOE Merit Review Presentations}

24. Steve Przesmitzki and Brian West, "Mid-Level Ethanol Blends Test Program,” presented at the 2009 U.S. DOE Biomass Program Infrastructure Peer Review, March 19, 2009, available at http://www.obpreview2009.govtools.us/infrastructure/documents/NREL_ORNL_OBP_Infrastruc ture_Review_2009_03_17_bw_sp_final.pdf

25. Keith Knoll, et al., "Mid-Level Ethanol Blends Test Program," presented at the 2009 U.S. DOE Hydrogen Program and Vehicle Technologies Program Annual Merit Review and Peer Evaluation Meeting, May 19, 2009, available at http://www1.eere.energy.gov/vehiclesandfuels/pdfs/merit_review_2009/fuel_technologies/ft_05_ knoll.pdf

26. Brian West, et al., "Mid-Level Ethanol Blends Test Program,” presented at the 2010 U.S. DOE Hydrogen Program and Vehicle Technologies Program Annual Merit Review and Peer Evaluation Meeting, June 9, 2010, available at http://www1.eere.energy.gov/vehiclesandfuels/pdfs/merit_review_2010/fuel_technologies/ft005_ west_2010_0.pdf.

27. Brian West, et al., "Intermediate Ethanol Blends Testing - Program Overview and Vehicle Testing,”presented at the 2011 U.S. DOE Biomass Infrastructure Review Meeting, February 2011, available at http://obpreview2011.govtools.us/presenters/public/AllPresentations.aspx

28. Tim Theiss, et al., "Preliminary Results from the ORNL Infrastructure Materials Compatibility Study” presented at the 2011 U.S. DOE Biomass Infrastructure Review Meeting, February 2011, available at http://obpreview2011.govtools.us/presenters/public/AllPresentations.aspx

29. Kristi Moriarty and Wendy Clark, "NREL UL Fuel Dispensing Infrastructure Intermediate Blends Performance Testing” presented at the 2011 U.S. DOE Biomass Infrastructure Review Meeting, February 2011, available at http://obpreview2011.govtools.us/presenters/public/AllPresentations.aspx

EPA E15 Rulings (Federal Register)

30. Federal Register, Vol. 75(213), Thursday, November 4, 2010, Notices.

31. Federal Register, Vol. 76(17), Wednesday, January 26, 2011, Notices. 